\title{
FOREWORD: UNDOING THE WORLD?
}

Many humans believe that the world should be exploited for our benefit, a perspective especially prominent in nations and peoples committed to the contemporary neoliberal economic model. While there are societies that place limits on destructive exploitation, and in some cases even practice sustainable processes for the use of the plants, animals, space, and land with which they share the planet, a majority of human societies, religions, political systems, and economic entities act as though they believe that humans have the right to use the world as they see fit. Today, in the twenty-first century, capitalist market economies have become dominant, and the human global population continues to increase at a colossal pace. The explosion in the extraction of biotic and abiotic resources has reached a scale and impact such that the only way humans could possibly continue in this vein is by having a confidence that the earth can sustain us regardless of what we do to it.

Such a belief is wholly false. We have the data.

The chemist Will Steffen and colleagues, in their now classic essay on the Anthropocene, tell us that "the human imprint on the global environment has now become so large and active that it rivals some of the great forces of Nature in its impact on the functioning of the Earth system." In 2017, a letter signed by more than sixteen thousand scientists from 184 countries titled "World Scientists' Warning to Humanity: A Second Notice" identified the key global trends in species extinctions, ozone depletion, carbon dioxide emissions, oceanic dead zones, temperature increase, the loss of forest, freshwater, and saltwater resources, and human population growth, which all portend approaching global catastrophe. In 2017, I joined a group of thirty-one primatology colleagues in publishing an article titled "Impending Extinction Crisis of the World's Primates: Why Primates Matter," focusing specifically on our close cousins, the other primates, identifying every major 
extinction threat, population loss, and habitat crisis, and determining that Ioo percent of the cause is us. ${ }^{2}$

The human commitment, investment, and devotion to drawing resources from our planet is not sustainable at our current pace or at our current level of global population. And it is, in part, particular beliefs in ourselves and our relations to the world that facilitated these processes of climate change and ecological disruption.

But then again, we humans are consummate niche constructors. We are ecosystem managers. It is our history, and future, to shape the world as it shapes us. With such endeavors come attendant ethical and practical responsibilities. We have the capacities to shape sustainable futures for ourselves and, by doing so, to shape sustainable processes for the ecosystems we are part of and the myriad other species with which we share them.

In order to do this, we have to seriously and effectively reflect on what we are doing and how we are doing it. The contemporary reality of our relations to all the others that share this planet requires that we shed traditional modes of explanation and understanding of what humans "do" with other species, and why. We need to develop novel, more entangled, and less myopic (less anthropic?) visions of where we are and where we are going. There is no better place to tackle this conundrum than by taking apart and putting back together that most human of all enterprises: domestication. And this is exactly what Marcus Baynes-Rock invites us to do. In this excellent narrative, Baynes-Rock takes us on a journey that is simultaneously visceral, intellectual, engaging, distressing, and compassionate, forcing readers to shed our restrictive lenses and recognize the undoing processes of what we so glibly call "domestication."

Humanity has been and is shaped by our caretaking, consumption, manipulation, and destruction of, and our compassion for, other beings. Human evolution is a multispecies endeavor, a current in which humans and our companion species have always been caught. A current sweeping countless others into the processes of human becoming-forcing them along for the ride, co-shaping our and their futures. This process of entanglement is more pervasive and broadly distributed in the Anthropocene than ever before. But this is not just a simple story of how humans bent other species to our will over the last ten thousand years, creating the tame and the wild. As Baynes-Rock so eloquently lays out for us, this is a story of undoing. A more terrifying and yet more plausible narrative. 
Take, for example, the chicken. There are more than twenty billion domestic chickens (Gallus gallus domesticus) on the planet at the moment, and because of our consumption patterns as many as three times that number will be born and eaten over the course of the next few years. By standard measures (the passing of genes from generation to generation), chickens, with their billions-strong population, are incredibly evolutionary successful. But can we actually say they've achieved any evolutionary success as a species? Without massive anthropogenic sustenance and structuring, they, in their contemporary biological forms, could not maintain anything close to current population levels. Driving home this point, Carys E. Bennett and colleagues argue that the chicken is actually a robust signal of a human reconfigured biosphere, noting that "chickens, now unable to survive without human intervention, have a combined mass exceeding that of all other birds on Earth; this novel morphotype symbolizes the unprecedented human reconfiguration of the Earth's biosphere." 3 To use Baynes-Rock's motif, we've "undone" the chicken. I am sure that every reader can instantly come up with more than a handful of other examples in which this undoing has wrenched species from particular trajectories and placed them squarely into others, unstructuring and restructuring what it means to be that species. For Baynes-Rock, it is "that which is taken away in the course of enfolding animals into human societies that in fact defines domestication." I agree, and I am certain that such a perspective is needed if we want to better understand where we (all of us, not just humans) are heading.

Baynes-Rock lays out a compelling argument that the key to understanding domestication is seeing it as the separation of animals from their traditional ecologies and incorporating (or forcing) them into a human niche-creating anthropogenic feeding, reproductive, and social systems wherein the animals (and maybe the humans too) become somewhat undone from one reality and melded into another.

But not all species are so easily undone. Nor have most human groups spent so much time and effort in the undoing as many in the contemporary geopolitical landscape do. Understanding this is the key to redoing at least some parts of the world. To drive this home, we accompany Baynes-Rock in his homeland of Australia, where he demonstrates myriad not quite domestic relations and uses them as a frame to show what is possible, impossible, and maybe even hopeful in humanity's engagement with others. This is his challenge to thinking simply with, about, and through "domestication." 
Traversing landscapes of humans, crocodiles, dingoes, stingless bees, emus, and kangaroos, Baynes-Rock illustrates a new wave of "domestication" that is not what we think it is. There are no villains, and no heroes. There are just people and animals, including the author, manipulating, interacting, reshaping, undoing, and redoing. The new wave of domestication is not a carefully orchestrated program of change; it is a haphazard process that carries people, animals, and ecologies into unfamiliar landscapes. It is what has been and is happening, and seeing such processes in this frame enables a new, and possibly hopeful, landscape.

Baynes-Rock ensures our attention, and offers both complication and enjoyment, as he invites the reader into his ethnography, his family, and his world. He takes us on a narrative journey that melds rigorous scholarship, innovative and engaging writing, and powerful storytelling, leading us to a shared conclusion. Undoing matters and redoing is possible, but not easy.

In this book, Baynes-Rock destroys a suite of dichotomies- "Culture is nature, mind is body, soul is body, human is animal"-enabling us to better understand that in this story of relations, "there is no good and evil, only roles within ecosystems." After reading this book, it becomes very difficult to see humans and the world as separate entities. The stories of multiple species in messy, entangled histories and presents give us a better glimpse of the reality wherein we are all enmeshed in a range of discordant tangles, some bringing us closer and others pushing us apart.

I can think of no better way to close this foreword than to quote from the end of the book to help the reader dive into the narrative with the understanding of where she will emerge: "We need to embrace complexity and learn to trust land, plants, and animals in ways that allow life to flow across landscapes, sometimes toward and sometimes away from us. Only then will we be able to reconnect, not only with the deep webs of complex ecologies, but with our humanity." 